\title{
Identification and initial characterization of stathmin by the differential display method in nerve growth factor-treated PC12 cells
}

\author{
Kazuhiro Takekoshi, Fumio Nomura, Kazumasa Isobe, Masahiko Motooka, Toru Nammoku and Toshiaki Nakai \\ Department of Clinical Pathology, Institute of Clinical Medicine, University of Tsukuba, Tsukuba, Ibaraki, Japan \\ (Correspondence should be addressed to K Takekoshi, Department of Clinical Pathology, Institute of Clinical Medicine, University of Tsukuba, Tsukuba, \\ Ibaraki, 305, Japan 1-1-1 Tennoudai, Tsukuba, 305, Japan)
}

\begin{abstract}
The differential display of mRNA is a new strategy to identify genes that are differentially expressed under altered conditions. We applied this method to determine differential gene expression in the rat pheochromocytoma cell line during differentiation induced by nerve growth factor (NGF).

Three different mRNA species were isolated, and their differential expression was confirmed by RTPCR. One of the mRNA species was identified as stathmin, a $19 \mathrm{kDa}$ cytosolic protein attracting increasing interest for its role in signal transduction. In the NGF-treated PC12 cells, the expression of stathmin mRNA increased in a time-dependent manner, as assessed by northern blot analysis and RTPCR. We also assessed by northern blot analysis how the expression of stathmin mRNA was altered in human pheochromocytomas $(n=5)$ compared with that in normal adrenal medulla tissue $(n=5)$. The mRNA concentrations were found to be significantly greater in the pheochromocytomas than in the normal tissues. It has been shown that stathmin mRNA concentrations are increased in various tumor cells. As pheochromocytomas are well-differentiated tumors of neural origin, it is not unexpected that stathmin mRNA is overexpressed in these tumors.

Stathmin was isolated and identified as a differentially expressed gene by the differential display method in PC12 cells during differentiation induced by NGF. In addition, stathmin mRNA was found to be overexpressed in human pheochromocytomas. The mechanisms responsible for the up-regulation of stathmin mRNA during differentiation of $\mathrm{PC} 12$ cells and the significance of its overexpression in human pheochromocytomas remain to be determined.
\end{abstract}

European Journal of Endocrinology 138 707-712

\section{Introduction}

The rat pheochromocytoma cell line is a useful model system for studying the nervous system at the single-cell level. In the presence of nerve growth factor (NGF), PC12 cells acquire neuronal characteristics such as the outgrowth of neurites and electrical excitability, suggesting that this system may facilitate the evaluation of changes in biochemical composition that accompany the NGF-induced differentiation of these cells $(1,2)$. Specific protein and gene expression profiles during the differentiation process of PC12 cells have been determined by various methods such as two-dimensional gel electrophoresis of cellular proteins and the differential screening of cDNA libraries (3-5). The information obtained by these methods, however, is somewhat limited.

The differential display of mRNA has been described as a new strategy to identify and isolate genes that are differentially expressed in various cells or under altered conditions (6-8). We describe here application of this method to identify differential gene expression in NGF-treated PC12 cells. Three different mRNA species were isolated, one of which has been identified as stathmin, a $19 \mathrm{kDa}$ cytosolic protein of interest for its role as a relay phosphoprotein for multiple signal transduction (9-15).

Although stathmin is expressed in a variety of cells and tissues (16), it is particularly abundant in the brain (17-19). This abundant expression of stathmin in the brain is due to its specific abundance in neurons. Chneiweiss et al. (19) determined the quantitative evolution of stathmin in relation to brain ontogenesis and demonstrated its potential involvement during neuronal differentiation. It is a generally held view that the activity of stathmin is modulated by phosphorylation and dephosphorylation of the molecule $(9,19)$. The results of the present study indicate that another level of regulation involving stathmin gene expression should also be considered during differentiation of neuronal cells. 
We also determined the expression of stathmin mRNA in human adrenal pheochromocytomas. The concentration of stathmin mRNA in pheochromocytomas was found to be significantly greater than that observed in normal adrenal medulla tissues.

\section{Methods}

\section{Cell culture}

The PC12 cell line (RCBO09) was obtained from the RIKEN Cell Bank (Ibaraki, Japan). Cells were grown to confluence at $37^{\circ} \mathrm{C}$ in $5 \% \mathrm{CO}_{2}$ in Dulbecco's modified essential medium (DMEM; Gibco BRL, MD, USA) containing 10\% inactivated horse serum (Gibco BRL) and 10\% fetal bovine serum (FBS; Gibco BRL). The culture medium was changed three times per week.

\section{Tissue samples}

Tumors specimens were obtained surgically from five patients with pheochromocytomas, and five normal adrenal glands were obtained at surgical nephrectomy for renal cell carcinoma. Each specimen was frozen at $-80^{\circ} \mathrm{C}$ until required for the assay. The pheochromocytomas specimens were all of adrenal origin.

\section{Differential display method}

Total RNA was extracted from differentiated PC12 cells (treated with $100 \mathrm{ng} / \mathrm{ml} \mathrm{NGF}$ (Gibco BRL) for $3 \mathrm{~h}$ ) and undifferentiated PC12 cells (untreated) using Isogen reagent (Nippon Gene, Tokyo, Japan). To obtain differentiation-specific or differentiation-related genes from PC12 cells, the differential display method was used. The differential display method (4-6) was carried out with some modifications. Briefly, $2.5 \mu \mathrm{g}$ deoxyribonuclease-I (Gene Hunter, Brookline, MA, USA)-treated total RNA was reverse transcribed (Super Script II, Gibco BRL) using oligo-dT primer (5'-GCG CAA GCT TTT TTT TTT TTG $\mathrm{C}-3^{\prime}$, designated as the $\mathrm{M}$ primer), and the cDNAs obtained were subsequently amplified by PCR using ten different random primers of 20 nucleotides. The reaction was carried out in a Program Temp Control System PC-700 (Astec, Fukuoka, Japan) for two cycles at $94^{\circ} \mathrm{C}$ for $3 \mathrm{~min}, 37^{\circ} \mathrm{C}$ for $5 \mathrm{~min}$, and $72^{\circ} \mathrm{C}$ for $5 \mathrm{~min}$, followed by $20-32$ cycles at $94^{\circ} \mathrm{C}$ for $30 \mathrm{~s}, 55^{\circ} \mathrm{C}$ for $1 \mathrm{~min}$, and $72^{\circ} \mathrm{C}$ for $2 \mathrm{~min}$. The PCR products were electrophoresed on a $6 \%$ DNA sequencing gel. The cDNA fragments which showed differential expressions were recovered from the gel and reamplified using the corresponding primer set. These cDNA fragments were cloned into the pCR II vector using a TA cloning kit (Invitrogen, San Diego, CA, USA) for further analysis. Each clone was sequenced by means of a fluorescencebased dideoxy sequencing method using Taq DNA polymerase and a fluorescently-labeled M13 universal sequencing primer. The sequencing reaction was carried out in a thermal cycler, and the data collection and analysis were carried out using an Applied Biosystems model 313A automated sequencer (Perkin Elmer, Foster City, CA, USA). The nucleotide sequences were analyzed for homology with sequences in the EMBL and GENEBANK databases using the BLAST (Basic Local Alignment Search Tool) program (BLAST network service).

\section{Time-course experiment}

The time course of expression of the candidate mRNA was obtained by quantitative RT-PCR and by northern blot analysis. For RT-PCR analysis, total RNA $(5 \mu \mathrm{g})$ treated with $100 \mathrm{ng} / \mathrm{ml} \mathrm{NGF}$ at $0,1,3$ and $8 \mathrm{~h}$, and 1,3 and 7 days was reverse transcribed using the oligo-dT (M) primer. The first-strand cDNAs were amplified by PCR using the specific primer set $(25$ pmol each) for stathmin. The PCR amplification was performed for 20 cycles at $94{ }^{\circ} \mathrm{C}$ for $30 \mathrm{~s}, 55^{\circ} \mathrm{C}$ for $1 \mathrm{~min}$, and $72^{\circ} \mathrm{C}$ for $2 \mathrm{~min}$. A program of 20 cycles was chosen as the basis of preliminary experiments that demonstrated a linear relationship between the input DNA and the RT-PCR product obtained under these conditions. Rat glyceraldehyde-3-phosphate dehydrogenase (G3PDH) cDNA was used as an internal standard (Clonetech, Palo Alto, CA, USA). The products were separated on a $2 \%$ agarose gel along with p-GEM markers, and stained with ethidium bromide. The oligonucleotide primers used in RT-PCR are within the coding region of the rat stathmin cDNA (21) and are as follows: sense from the $5^{\prime}$ coding region, corresponding to bases 200-221 (5'-GGA GAA GCG AGC TTC CGG-3', designated as ST-1-5'); antisense from the coding region corresponding to bases 618639 (5'-AAG TCA GTT CTC GGA ACA ACT-3'; designated as ST-1-3'). The RT-PCR products were confirmed as stathmin by direct sequencing using ST-15' as the forward primer and ST-1-3' as the reverse primer.

For northern blot analysis, total RNA was extracted from the sample treated with $100 \mathrm{ng} / \mathrm{ml} \mathrm{NGF}$ at 0 and $3 \mathrm{~h}$ using an Isogen kit (Nippon Gene). The RNA concentration was determined spectrophtometrically (absorbance at $260 \mathrm{~nm})$. RNA $(10 \mu \mathrm{g}$ sample) was fractionated by electrophoresis on $1 \%$ agarose/5\% formaldehyde gels $(80 \mathrm{~V}$ for $2 \mathrm{~h})$. After staining with ethidium bromide and a visual inspection of the UV fluorescence to confirm the presence of equal amounts of $18 \mathrm{~S}$ and $28 \mathrm{~S}$ ribosomal RNA in each lane, the RNA was transferred to a nitrocellulose membrane and hybridized to ${ }^{32} \mathrm{P}$-labeled probes. The cDNA fragment encoding part of the coding region was obtained by RT-PCR and verified as stathmin as described above and used as a probe. First-strand cDNA was synthesized from total RNA extracted from untreated PC12 cells. The following PCR was performed as described in the quantitative PCR method. The probe was labeled using 
a random primer extension labeling kit (New England Nuclear, Boston, MA, USA ). Rat G3PDH cDNA was used as an internal standard (Clonetech). Hybridization signals were scanned in an image analyzer (BAS2000, Fuji, Tokyo, Japan).

\section{Expression of stathmin mRNA in human pheochromocytomas and normal adrenal glands}

Total RNA was extracted from the frozen tissues. Northern blot analysis was performed as described above. A cDNA sequence corresponding to the $3^{\prime}$-region of rat stathmin was used as a probe.

\section{Statistical analysis}

The significance of differences between the data was determined by Student's $t$-test and the significance level set at $P<0.05$. Values are expressed as means \pm s.D.

\section{Results}

\section{Detection of the dominantly expressed mRNA in differentiated PC12 cells by the differential display method}

RNAs isolated from differentiated cells (treated with $100 \mathrm{ng} / \mathrm{ml} \mathrm{NGF}$ for $3 \mathrm{~h}$ ) and undifferentiated cells (untreated) were used. A total of 46 candidate cDNAs that demonstrated altered expression between NGFtreated and -untreated cells were obtained. A representative example is presented in Fig. 1. These bands were recovered from the gel, reamplified, cloned and sequenced. Of the 46 candidate cDNAs, nine failed to be reamplified by RT-PCR. Thirty-four bands were found to be comparable between NGF-treated and -untreated cells in reamplified samples. Consequently, the remaining three candidate clones were considered positive. The sequence of one of these clones showed 100\% homology with the $3^{\prime}$ region of the rat stathmin. Another was an anonymous clone, and the third had no database match.

\section{Time course of expression of the stathmin gene during differentiation induced by NGF in PC12 cells}

As shown in Fig. $2 a$, the expression of stathmin mRNA increased in a time-dependent manner, peaked at 1 day, and decreased thereafter. This finding obtained by quantitative RT-PCR was confirmed with northern blot analysis, which showed that stathmin mRNA was more abundant in the NGF treated $(3 \mathrm{~h}) \mathrm{PC} 12$ cells than in the untreated cells (Fig. 2b), confirming that stathmin mRNA concentrations differed between the NGF-treated

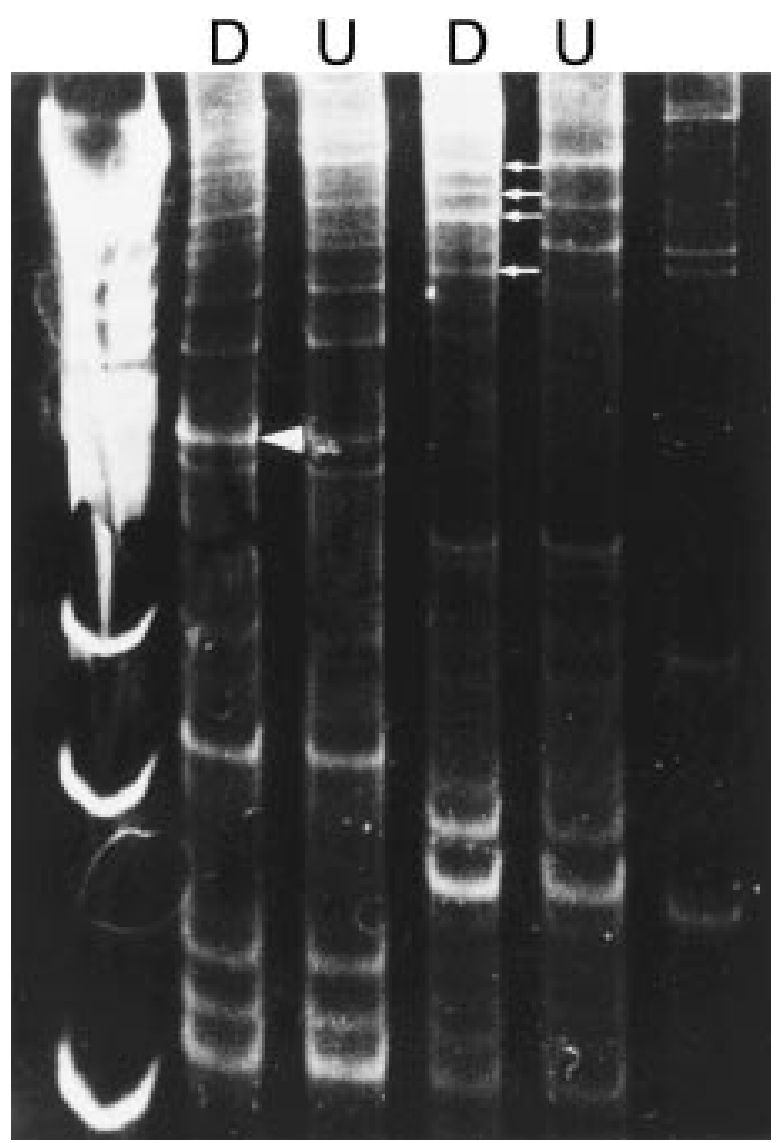

Figure $1 \mathrm{~A}$ representative result of the differential display method applied to PC12 cells. Candidate cDNAs that demonstrated altered expression between differentiated cells (treated with $100 \mathrm{ng} / \mathrm{ml} \mathrm{NGF}$ for $3 \mathrm{~h}$ ) and undifferentiated cells (untreated) are marked by arrows. The band corresponding to stathmin is indicated by the arrowhead. $\mathrm{U}$, untreated (control); $\mathrm{D}$, treated with NGF for $3 \mathrm{~h}$.

and -untreated cells under the experimental conditions of our differential display technique.

\section{Expression of stathmin mRNA in human pheochromocytomas}

As revealed by northern blot analysis (Fig. 3a), the concentration of stathmin mRNA was greater in pheochromocytomas than in normal tissues. The difference was found to be significant $(P<0.05)$ when the equivalent areas in the autoradiograms were quantified by densitometry (Fig. 3b).

\section{Discussion}

The major goal of this study was to isolate and identify genes differentially expressed during the differentiation of NGF-treated PC12 cells, using the differential display method (6-8). Three different mRNA species were isolated, one of which was found to be stathmin. Stathmin is a cytosolic phosphoprotein that was 
(a)

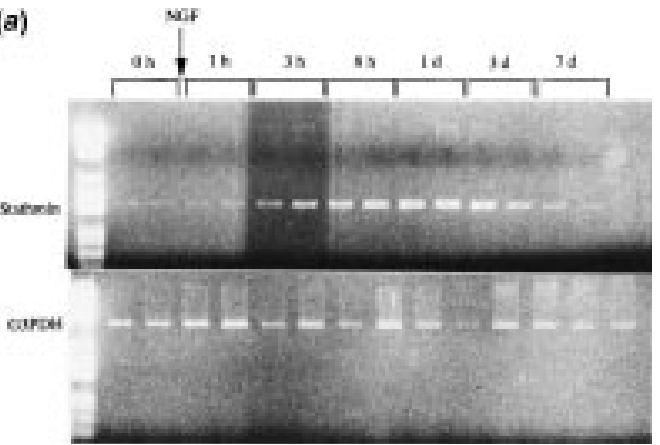

originally identified on the basis of its high level of expression in leukemic cells (13). Different investigators have also named this protein $\mathrm{P} 18, \mathrm{P} 19$, prosolin and metablastin (9-15). Stathmin is proposed to be an intracellular relay which may integrate the actions of a variety of signals that regulate proliferation, differentiation and other cellular functions (9). It has been shown that stathmin is phosphorylated in response to NGF in PC1 2 cells, which in turn may regulate their differentiation $(20,21)$. Also, it has been reported (22) that a selective blockade of the expression of stathmin by antisense oligonucleotide prevented the differentiationpromoting actions of NGF. Thus our observation that stathmin was differentially expressed as assessed by differential display in NGF-treated PC12 cells is compatible with previous reports indicating that stathmin has a crucial role in the differentiation of PC12 cells $(20,22)$.

It is a general view that the activity of stathmin is modulated by phosphorylation and dephosphorylation of the molecule as a short-term mechanism of regulation. The results of this study indicate that another level of regulation involving expression of the stathmin gene should also be considered. As shown in Fig. 2, the expression of stathmin mRNA increased in a time-
Figure 2 Time course of changes in concentrations of stathmin mRNA during differentiation induced by NGF in PC12 cells. PC12 cells were stimulated with NGF for the times indicated. (a): Quantitative RT-PCR; reactions were carried out in duplicate. The upper panel shows that stathmin mRNA concentrations increased in a time-dependent manner. The lower panel shows control mRNA (G3PDH), which contained an amount of mRNA equivalent to that loaded in each lane. (b): Northern blot analysis confirmed the finding obtained by quantitative RT-PCR: stathmin mRNA was more abundant in NGFtreated $(3 \mathrm{~h}) \mathrm{PC} 12$ cells than in the untreated cells. The lower panel shows control mRNA (G3PDH). Similar results were obtained in two other experiments. dependent manner during NGF treatment of PC12 cells. We speculate that two different mechanisms of regulation of stathmin functions, one by phosphorylation and de-phosphorylation, and the other mediated by changes in gene expression, may work in concert.

The mechanism of this up-regulation of stathmin mRNA expression during differentiation is not known at present. When leukemic cells were induced to differentiate in vitro, down-regulation of stathmin expression was observed (23). It has also been reported (24) that the mechanism responsible for the down-regulation was a decrease in its rate of transcription rather than a change in its mRNA stability. Evaluation of the stability and rate of transcription of mRNA (for example by means of a nuclear run-on assay) will be needed to clarify further the significance of up-regulation of the expression of stathmin mRNA during differentiation in PC12 cells.

Another interesting observation made in this study was that the concentration of stathmin mRNA in human pheochromocytomas were significantly greater than those in normal adrenal medulla tissues. Other studies have indicated that stathmin can be phosphorylated in vivo by two forms of mitogen-activated protein (a)

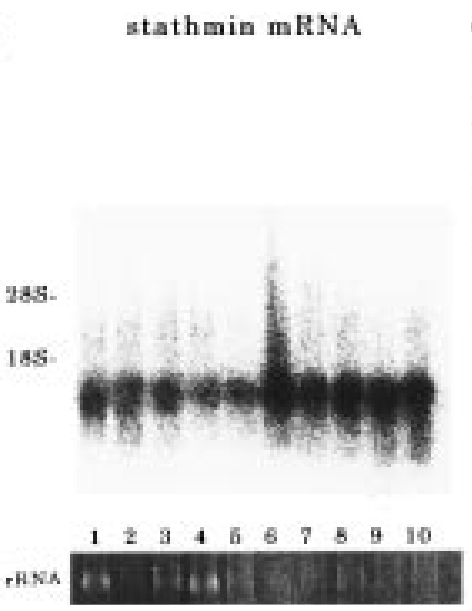

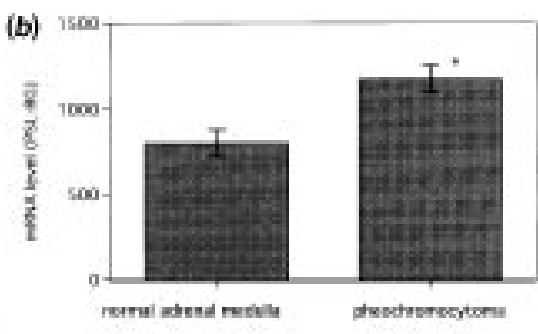

Figure 3 Stathmin mRNA concentrations in human pheochromocytomas. (a) Total cellular RNA (10 $\mu \mathrm{g} /$ lane) from normal adrenal medulla tissues (lanes 1-5) and pheochromocytoma tissues (lanes 6-10) were characterized by northern blot analysis. (b) Mean \pm s.D. values of the radioactivities (photostimulated luminescencebackground) of the stathmin mRNA in normal adrenal medullas and pheochromocytoma tissues. *Significantly different $(P<0.05)$ from normal adrenal medulla tissues. 
kinase (MAPK), and that these stathmin kinases are activated after NGF treatment in PC12 cells $(25,26)$. MAPKs belong to a family of intracellular protein serine/threonine kinases that are activated by phosphorylation in response to a variety of extracellular signals. Indeed, it has been postulated that MAPK kinases and MAPK have direct roles in the secretagogue-induced catecholamine release in bovine adrenal chromaffin cells (27). It is tempting to speculate that the increase in stathmin mRNA in pheochromocytomas is associated with the catecholamine metabolism in these tumors. These points remain to be clarified.

It is paradoxical that stathmin mRNA, differentially expressed while PC12 cells undergo NGF-induced differentiation, is overexpressed in pheochromocytomas. This discrepancy implies that the target molecules of the activated stathmin may not be the same in PC12 cells and human pheochromocytomas. A similar paradox has been observed before: Borrello et al. (28) transfected NIH 3T3 and PC12 cells with MEN2A and MEN2B RET constructs. Specific-point mutations of RET, which codes for a receptor tyrosine kinase, are responsible for MEN2A and MEN2B. It was found that transformation was induced in the NIH $3 \mathrm{~T} 3$ cells and differentiation occurred in the PC12 cells.

An increase in stathmin mRNA has been reported in various tumor cells, and its expression appears to be essential for the differentiation of neural cell lineages. As pheochromocytomas are well-differentiated tumors of neural origin, it is not unexpected that stathmin mRNA is overexpressed in these tumors. The difference in the expression of stathmin mRNA between pheochromocytomas and normal adrenal medullas was only marginally significant, and should be interpreted with caution. The significance of the presence of increased stathmin mRNA in human pheochromocytomas remains to be clarified.

As described above, two different mRNA species other than stathmin mRNA were isolated, and one had no match in any available database. Experiments are currently in progress to characterize this unidentified clone.

\section{References}

1 Green LA \& Tischler AS. Establishment of a noradrenergic clonal line of rat adrenal pheochromocytoma cells which respond to nerve growth factor. Proceedings of the National Academy of Sciences of the USA $1976732424-2428$.

2 Green LA \& Tischler AS. PC12 pheochromocytoma cultures in neurobiological research. Advances in Cell Neurobiology 19823 373-414.

3 McGuire JC, Greene LA \& Furano AV. NGF stimulates incorporation of fucose or glucosamine into an external glycoprotein in cultured rat PC12 pheochromocytoma cells. Cell $197815357-$ 365.

4 Anderson DJ \& Axel R. Molecular probes for the development and plasticity of neural crest derivatives. Cell $198542649-662$.

5 Levi A, Eldridge JD \& Paterson BM. Molecular cloning of a gene sequence regulated by nerve growth factor. Science 1985229 393-395.
6 Liang P \& Pardee AB. Differential display of eukaryotic messenger RNA by means of the polymerase chain reaction. Science 1992 257 967-971.

7 Liang P, Averboukh L, Keyomarsi K, Sager R \& Pardee AB. Differential display and cloning of messenger RNAs from human breast cancer versus mammary epithelial cells. Cancer Research $1992526966-6968$.

8 Linskens MHK, Feng J, Andrews WH, Enlow BE, Saati SM, Tonkin LA et al. Cataloging altered gene expressions in young and senescent cells using enhanced differential display. Nucleic Acid Research 199523 3244-3251.

9 Sobel A. Stathmin: a relay phosphoprotein for multiple signal transduction? Trends in Biochemical Sciences 199116 301-305.

10 Pasmantier R, Danoff A, Fleischer N \& Schubart UK. P19, a hormonally regulated phosphoprotein of peptide hormoneproducing cells: secretagogue-induced phosphorylation in AtT-20 mouse pituitary tumor cells and in rat and hamster insulinoma cells. Endocrinology 1986119 1229-1238.

11 Braverman R, Bhattacharya B, Feuerstein N \& Cooper HL. Identification and characterization of the nonphosphorylated precursor of pp17, a phosphoprotein associated with phorbol ester induction of growth arrest and monocytic differentiation in HL-60 promyelocytic leukemia cells. Journal of Biological Chemistry $198626114342-14348$.

12 Gullberg M, Noreus K, Brattsand G, Friedrich B \& Shingler V. Purification and characterization of a 19-kilodalton intracellular protein. An activation-regulated putative protein kinase C substrate of T lymphocytes. Journal of Biological Chemistry 1990 265 17499-17505.

13 Hanash SM, Strahler JR, Kuick R, Chu EH \& Nichols D. Identification of a polypeptide associated with the malignant phenotype in acute leukemia. Journal of Biological Chemistry 1988 263 12813-12815.

14 Hailat N, Strahler J, Melhem R, Zhu XX, Brodeur G, Seeger RC et al. $\mathrm{N}$-myc gene amplification in neuroblastoma is associated with altered phosphorylation of a proliferation related polypeptide (Op18). Oncogene 19905 1615-1618.

15 Schubart UK, Xu J, Fan W, Cheng G, Goldstein H, Alpini G et al. Widespread differentiation stage-specific expression of the gene encoding phosphoprotein p19 (metablastin) in mammalian cells. Differentiation $19925121-32$.

16 Rowlands DC, Williams A, Jones NA, Guest SS, Reynolds GM, Barber PC et al. Stathmin expression is a feature of proliferating cells of most, if not all, cell lineages. Laboratory Investigation 1995 72 100-113.

17 Himi T, Okazaki T \& Mori N. SCG10 mRNA localization in the hippocampus: comparison with other mRNAs encoding neuronal growth-associated proteins (nGAPs). Brain Research 1994655 177-185.

18 Peschanski M, Hirsch E, Dusart I, Doye V, Marty S, Manceau V et al. Stathmin: cellular localization of a major phosphoprotein in the adult rat and human CNS. Journal of Comparative Neurology $1993337655-668$.

19 Chneiweiss H, Beretta L, Cordier J, Boutterin MC, Glowinski J \& Sobel A. Stathmin is a major phosphoprotein and cyclic AMPdependent protein kinase substrate in mouse brain neurons but not in astrocytes in culture: regulation during ontogenesis. Journal of Neurochemistry 198953 856-863.

20 Doye V, Boutterin MC \& Sobel A. Phosphorylation of stathmin and other proteins related to nerve growth factor-induced regulation of PC-12 cells. Journal of Biological Chemistry 1990265 1165011655.

21 Doye V, Soubrier F, Bauw G, Boutterin MC, Beretta L, Koppel J et al. A single cDNA encodes two isoforms of stathmin, a developmentally regulated neuron-enriched phosphoprotein. Journal of Biological Chemistry 1989264 12134-12137.

22 Di Paolo G, Pellier V, Catsicas M, Antonsson B, Catsicas S \& Grennigloh G. The phosphoprotein is essential for nerve growth factor stimulated differentiation. Journal of Cellular Biology 1996 133 1383-1390. 
23 Mistry S, Luox N \& Atweh GF. Transcriptional regulation of phosphoprotein p18 during monocytic differentiation of U937 leukemic cells. Cellular and Molecular Biology Research 199541 103-110.

24 Luox N, Arcasoy MO, Brickner HE, Mistry S, Schechter AD \& Atweh GF. Regulated expression of p18, a major phosphoprotein of leukemic cells. Journal of Biological Chemistry 1991266 21004-21010

25 Leighton IA, Curmi P, Campbell DG, Cohen P \& Sobel A. The phosphorylation of stathmin by MAP kinase. Molecular and Cellular Biochemistry 1993 127-128 151-156.

26 Beretta L, Dobransky T \& Sobel A. Multiple phosphorylation of stathmin. Identification of four sites phosphorylated in intact cells and in vitro by cyclic AMP-dependent protein kinase and p34cdc2. Journal of Biological Chemistry 1993268 2007620084.

27 Cox ME, Ely CM, Catling AD, Weber MJ \& Parsons SJ. Tyrosine kinases are required for catecholamine secretion and mitogen-activated protein kinase activation in bovine adrenal chromaffin cells. Journal of Neurochemistry 199666 1103-1112. 28 Borrello MG, Smith DP, Pasini B, Bongarzone I, Greco A, Lorenzo MJ et al. RET activation by germline MEN2A and MEN2B mutations. Oncogene 199511 2419-2427.

Received 29 September 1997

Accepted 23 February 1998 